\title{
Darwin na Serra da Tiririca: caminhos entrecruzados entre a biologia e a história*
}

\author{
Sandra Escovedo Selles \\ Universidade Federal Fluminense, Faculdade de Educação
}

Martha Abreu

Universidade Federal Fluminense, Departamento de História

\section{Introdução}

Os estudos a respeito do meio ambiente ganharam, nas últimas décadas, uma importância significativa em diversos segmentos da sociedade. A constatação dos problemas da ação humana em relação ao mundo natural provocou, nesse período, uma curiosa inversão na posição da centralidade do homem. Algo mudou, desde a aceitação da supremacia humana sobre o ambiente natural, fomentada pelas idéias baconianas, que situavam a finalidade do saber científico em melhorar a vida humana, dotando-a com novas invenções e riquezas.

* Expressamos nosso agradecimento à professora Ana Angélica Barros, da Faculdade de Formação de Professores da UERJ, que trilha há diversos anos os caminhos da Serra da Tiririca, realizando estudos botânicos e ambientalistas, e que, desde o início do projeto, nos inspira com seus conhecimentos e nos contagia com seu afeto pela Serra. Agradecemos também às professoras Lori Pietzsch e Maria Ferreira, por estarem juntas conosco nas atividades do "Revisitando os caminhos de Darwin na Serra da Tiririca", o que, sem dúvida alguma, foi fundamental para este estudo.
O enfraquecimento dessas idéias, em diferentes níveis e dimensões, clama por uma revisão profunda das bases do pensamento científico e, por conseguinte, de seus reflexos na sociedade, a respeito do trato do meio ambiente, recolocando problemas, buscando soluções, desenvolvendo estudos e propondo diferentes formas de agir (Grün, 1996). Podemos considerar que o momento da grande divulgação ambientalista, dando ênfase à vilania humana - o homem assassino de baleias, jacarés, gorilas etc. -, revelou uma posição quase ingênua das questões ambientais e, nesse bojo, a biologia (e particularmente a ecologia) foi eleita como a ciência salvadora dos destinos do planeta. Muitos estudos brasileiros, entretanto, têm sido enfáticos em criticar tal posição e apontar a necessidade de uma abordagem para os problemas ambientais que leve em conta a complexidade do seu objeto e o defina com base em elementos econômicos, culturais, sociais e históricos oriundos de diversas áreas do conhecimento (Reigota, 2001; Grün, 1996; Dias, 1998; Barzano, 2000; Layargues, 2001; Vianna, 2002, entre muitos).

Neste artigo exploramos uma possibilidade de estudo do ambiente com vistas ao desenvolvimento 
de valores. Nosso enfoque será uma abordagem pedagógica, voltada para professores, reunindo elementos socioistóricos a respeito de um determinado ambiente ameaçado. Trata-se do Parque Nacional da Serra da Tiririca, localizado na região fronteiriça entre os municípios de Niterói e Maricá, no estado do Rio de Janeiro, alvo de disputas políticas e econômicas que envolvem tanto especulações imobiliárias como ações ilegais de desmatamento, posse de terra e crimes ambientais variados.

Para este estudo, partimos de um levantamento histórico do ambiente, motivadas pela leitura de algumas partes do Diário de um naturalista ao redor do mundo, de Charles Darwin (1809-1882). ${ }^{1}$ Esse livro foi escrito a bordo do navio H.M.S. Beagle, quando, em 1832, visitou o Brasil, particularmente a região entre as cidades do Rio de Janeiro e de Niterói e o norte de Cabo Frio. A passagem de Darwin pela Serra da Tiririca despertou-nos a curiosidade, porque éramos duas professoras de biologia e história compartilhando interesses e territórios, já que residentes nas vizinhanças do Parque Estadual da Serra da Tiririca. ${ }^{2}$ Tal encontro teve um desdobramento de ordem pedagógica muito particular e gerou um conjunto de reflexões a respeito do uso do registro histórico em projetos voltados para docentes, que nos conduziu a um caminho entre a história e a biologia nem sempre explícito para muitos professores e alunos.

De início, problematizamos a questão ambiental, buscando justificar a propriedade da conjugação de diferentes olhares disciplinares em trabalhos educativos desse escopo. Argumentaremos na direção de uma abordagem para o tratamento das questões ambientais que fuja do formato normativo, ou seja, que privilegia ações desprovidas de uma reflexão mais aprofundada a respeito das relações socioistóricas imbricadas

${ }^{1}$ Darwin, 1937. Parte desse Diário foi republicada pela ditora Paz e Terra, em 1996, com o título O Beagle na América Latina.

${ }^{2}$ É preciso destacar a singularidade deste ambiente, uma vez que ocupa uma área considerável (2.400 ha) em um município com uma extensão territorial tão reduzida como o de Niterói. nessas questões. Layargues (2001) refere-se a essa questão, criticando abordagens que adotam uma perspectiva reformista e com contornos de "adestramento ambiental" (p. 140), expressão também utilizada por Brügger (1994). Em seguida, analisamos as possibilidades de um trabalho de formação continuada de professores, discutindo o potencial da utilização de registros históricos como subsídio para o trabalho docente.

A contribuição da história, conforme dela nos servimos, sugere uma possibilidade de utilizar um registro histórico como tema gerador ${ }^{3}$ em trabalhos ambientais. Primeiro, porque permite ampliar a visão sobre o ambiente, dimensionando-o no tempo humano, recolocando limites, estabelecendo fronteiras e, sobretudo, revelando a multiplicidade de olhares disciplinares que se fazem necessários para uma análise mais cuidadosa. Além disso, uma leitura histórica que ressignifique a passagem de Darwin pela Serra da Tiririca $^{4}$ pode ser considerada suficientemente fértil, como foram as anotações que fez no seu diário. Buscaremos situar este autodenominado naturalist $a^{5}$ no contexto em que viveu - neste caso, em particular, ao tempo de sua passagem pelo Rio de Janeiro - e também, com base em uma interpretação de sua visão sobre o Brasil, redimensionar o lugar que as suas reflexões, ao tomarem contato com a diversidade brasileira em tal nível de abundância, ocuparam na mente desse intelectual para elaboração da teoria da evolução. ${ }^{6}$ Fi-

${ }^{3}$ A idéia de tema gerador é, obviamente, associada aos trabalhos de Paulo Freire.

${ }^{4} \mathrm{Na}$ verdade, as referências que Darwin faz à Serra da Tiririca não são tão numerosas, mas para os fins deste trabalho foram significativas.

${ }^{5}$ No Diário de um naturalista ao redor do mundo, Darwin, por diversas vezes, refere-se a si mesmo como naturalista, bem como em sua autobiografia.

${ }^{6}$ Faremos referência, neste texto, à teoria da evolução como darwinista. Reconhecemos, entretanto, que a autoria dessa teoria é compartilhada por Alfred Russel Wallace, a partir do célebre artigo lido em conjunto na Linnean Society of London, em $1^{\circ}$ de julho de 1858. 
nalizamos argumentando que o estudo piloto desenvolvido com professores recoloca o tratamento das questões ambientais na direção de valores de pertencimento, aprofundando um enraizamento sociocultural, e que, ancorado pela abordagem histórica, parece fundamental.

\section{Recolocando o problema ambiental para os professores}

Nosso ponto de partida foi um exercício de reconstrução histórica das transformações de um ambiente, iniciado com a leitura dos escritos de Charles Darwin, no registro de sua passagem pelo Rio de Janeiro. Nosso propósito era identificar o caminho que ele teria seguido quando percorreu a estrada que margeia a Serra da Tiririca (nos limites dos municípios de Niterói e Maricá), dirigindo-se ao norte de Cabo Frio. Por qual estrada teria ele seguido? De que escritos, presentes no Diário, poderíamos nos utilizar para responder a essa pergunta? Que outros naturalistas teriam visitado a região?

Além disso, começamos a pensar nos contrastes entre o ambiente visitado por Darwin e a Serra da Tiririca nos dias atuais, que, apesar das marcas da devastação, ainda guarda sua exuberância. Assim, dessa leitura e desse esforço de imaginação, questionamonos se seria possível utilizar os registros históricos deixados por Darwin e explorá-lo pedagogicamente. Pareceu-nos fundamental envolver escolas e professores que também desejassem conhecer um pouco mais esse ambiente natural, não unicamente na sua dimensão biológica, mas também desejosos de compreender como a ocupação humana imprimiu, historicamente, as marcas nesse ambiente. Perguntávamos, ainda, em que medida o emprego da história poderia nos ajudar a significar e ressignificar essa ocupação e, por conseguinte, como ampliaria o conhecimento de professores em seus diversos territórios disciplinares.

Tínhamos, na verdade, duas hipóteses de trabalho. A primeira delas levava-nos a pensar que seria possível utilizar esta estratégia (o registro da passagem de Darwin pela Serra da Tiririca) como tema ge- rador de um trabalho pedagógico voltado para o conhecimento de um ambiente natural. Considerávamos que dessa forma poderíamos superar uma abordagem ambientalista limitada simplesmente a uma leitura biologizante. A segunda hipótese, conseqüência da primeira, sugeria que convergir para esse ambiente diferentes olhares disciplinares permitiria um enriquecimento cultural de tal ordem que, potencialmente, poderia ser utilizado como referência para o desenvolvimento de valores em relação ao ambiente. Entendemos que esses valores podem servir de base para uma ação participativa que estabeleça vínculos e acentue uma relação identitária, trazendo, como conseqüência, o gosto, o respeito pelo ambiente bem como o cuidado com ele.

Tomamos como premissa que as formas mais comuns de abordar problemas ambientais se mostram insuficientes porque partem de uma perspectiva externa ou normativa para tratar esses problemas. Parece-nos impossível apontar soluções sem desvendar os complexos caminhos socioistóricos que configuraram um problema atual. Conforme defende Layargues (2001), a resolução de problemas ambientais não pode ser considerada atividade fim e, neste sentido, aproximamos-nos da abordagem teórica esquematizada por Viola (apud Layargues, 2001) como movimento histórico.

Usamos um registro histórico como tema gerador para o tratamento de um problema ambiental local, não como um fim em si mesmo, mas porque ele nos permitiu explorar diferentes ângulos da questão. De forma coerente com esse princípio, essa abordagem se colocava em oposição a uma visão de adestramento ambiental (Layargues, 2001). Acreditamos que uma conscientização em relação ao ambiente (em níveis de complexidades variadas) pode emergir mais intensamente se aprofundarmos a relação entre os cidadãos e o problema ambiental que se tem à frente, vivido e percebido por muitos deles de formas diferenciadas. Esses questionamentos parecem sugestivos para um exame do tratamento curricular proposto para as escolas baseado nos Parâmetros Curriculares Nacionais, que colocam o meio ambiente como tema 
transversal. Da mesma forma, a utilização de um registro histórico com tema gerador permite-nos tecer considerações sobre a Política Nacional de Educação Ambiental $^{7}$ e a vertente socioambiental, com a abordagem culturalista adotada nos países do Terceiro Mundo, e fortalece nosso propósito de discutir problemas ambientalistas de forma significativa com base em um enfoque local, como o pretendido. Adotar problemas ambientais locais como um tema gerador para atividades escolares, conforme propomos, potencializa a reflexão - a respeito das questões ecológicas, históricas, socioculturais e educacionais -, tanto quanto a ação, e pode vir a ser uma prática pedagógica transformadora que desperte a visão crítica e a responsabilidade social nos educandos, e contribua para a formação da sua cidadania.

A cultura escolar tem colocado nas mãos do professor de ciências e biologia a responsabilidade de encaminhar e tratar as questões ambientais, posição esta que, vagarosamente, vem sendo assumida por outros campos disciplinares. No presente estudo, pretendemos oferecer elementos que encorajem iniciativas para encontrar interfaces disciplinares nesses trabalhos, e sugerimos a conjugação da biologia com a história como uma possibilidade profícua. O entendimento da história da ocupação humana da Serra da Tiririca significa, para nós, enfrentar a problemática na perspectiva dos professores e oferecer-lhes alternativas que lhes ampliem a visão de mundo e a visão sobre o seu trabalho docente (Behrsin, 2001). Em outras palavras, pretendemos contribuir para ampliar seu conhecimento sobre sua disciplina de referência, incorporando novas visões advindas de outros campos disciplinares que lhes tragam, em retorno, melhor redefinição de seu próprio objeto de ensino. Com isso, queremos pontuar que o ambiente - Serra da Tiririca - não representou apenas nosso ponto de partida, mas também conferiu uma singularidade valiosa para este estudo. Nosso locus de reflexão trabalha na interface tanto do ambiente focalizado como também das possibilidades de um traba-

${ }^{7}$ Lei $n^{\circ} 9.795$, de 27 de abril de 1999. lho de formação continuada, que engendre o crescimento do professor e da geração que o acompanha. É, portanto, este o nosso ponto de chegada.

\section{O trabalho com os professores: revisitando os caminhos de Darwin na Serra da Tiririca}

Com essas questões em mente, passamos a pensar que seria importante refazermos o breve percurso narrado por Darwin até a localidade conhecida como Itaocaia (citada no Diário como Itacaia). Para isso, deveríamos convidar algumas escolas que pudessem compartilhar nossa proposta, olhando juntas para o mapa do século XIX, situando localidades e refletindo sobre as mudanças ocorridas tanto no plano biológico quanto no social. Pretendíamos, de forma nãodiretiva, oferecer oportunidades para que os próprios professores vislumbrassem encaminhamentos pedagógicos para seu trabalho escolar.

Seguimos, dessa forma, "a estratégia da resolução de problemas ambientais locais na busca de uma aproximação do vínculo entre os processos educativos e a realidade cotidiana dos educandos" (Layargues, 2001, p. 133). Como a ação local é apontada como oportunidade privilegiada para o enfrentamento dos problemas ambientais, a ameaça à Reserva da Serra da Tiririca foi objeto de análise, considerando a complexa interação dos aspectos ecológicos com os políticoeconômicos e socioculturais da questão ambiental.

Como referido anteriormente, partimos da possibilidade de conjugar diferentes olhares disciplinares para estudar o ambiente, e para isso foi necessária a formação de uma equipe multidisciplinar nas escolas. Esse trabalho foi realizado com nove escolas dos municípios de Niterói e Maricá, e compreendeu três etapas: 1) pesquisa dos registros históricos relacionados à passagem de alguns naturalistas pela região ${ }^{8} \mathrm{e}$

${ }^{8}$ Além do Diário de um naturalista ao redor do mundo, de Darwin (1937), também incluímos A rota dos diamantes, de Auguste de Saint-Hilaire, e Viagem ao Brasil, do príncipe Maximiliano de Wied Neuwied. 
localização de mapas da região, do século XIX e atuais; 2) organização da atividade "Revisitando os caminhos de Darwin na Serra da Tiririca", dirigida aos professores das escolas participantes, compreendendo a realização de uma caminhada seguindo o roteiro de Darwin até Itaocaia, no município de Maricá; 3) encontro pedagógico em uma das escolas, para promover um debate interdisciplinar com os professores que fizeram a caminhada e com os professores especialistas responsáveis pela condução do debate.

A pesquisa dos registros históricos e o mapa de 1851, encontrado na Biblioteca Nacional, permitiram a reconstituição da trajetória e identificação da estrada utilizada por Darwin. Os dados indicaram-nos que Darwin aportou em Niterói (Praia Grande) e, guiado por tropeiros, chegou à Região Oceânica (nome atual para as terras que se situam fora da Baía de Guanabara e que outrora faziam parte da Freguesia de Itaipu), uma vez que relata: "A paisagem que se descortinava quando estávamos cruzando as montanhas atrás da Praia Grande (...)". ${ }^{9}$ A descrição da Serra da Tiririca é explícita: "Depois de passarmos por alguns campos cultivados, entramos numa floresta cuja magnificência não podia ser superada”. Darwin prossegue por uma estrada, que ainda pode ser trilhada, até chegar à casa central em Itaocaia. ${ }^{10}$

Esse trajeto foi revisitado, em 2000, por 34 participantes, na companhia de estudiosos da região que descreviam aspectos biológicos, apontavam os pontos mais ameaçados, identificavam localidades situando-as historicamente etc. Em Itaocaia houve uma discussão sobre as possibilidades pedagógicas de as escolas realizarem o projeto com os alunos, com base

${ }^{9}$ Todas as citações de Darwin sobre esta viagem podem ser encontradas no capítulo 2 de O Beagle na América do Sul, p. 1322. A descrição da estada no Rio de Janeiro encontra-se entre as páginas 22 e 23 . Optamos por utilizar essa edição do texto de Darwin, na verdade apenas parte do Diário de um naturalista ao redor do mundo, por ser a edição mais recente e estar disponível.

${ }^{10}$ A casa central, referida por Darwin em seu relato, é hoje chamada de Hotel Fazenda Século XVIII (Foto 1). na experiência realizada e nas fontes históricas que foram disponibilizadas de todos os participantes. Como dissemos, em vez de oferecer propostas construídas com base em nossa forma de perceber o problema ambiental, nossa intenção era deixar que os professores se apropriassem do vivido naquele momento, reunissem o material que lhes trazíamos e voltassem às suas escolas para pensar formas de encaminhar seus projetos. ${ }^{11}$

Dois meses após essa atividade, foi realizado um encontro em uma das escolas participantes do projeto, com a presença de uma historiadora e de uma botânica que estuda a flora da região. ${ }^{12} \mathrm{O}$ debate realizado na escola, "O Brasil que Darwin viu e o Brasil que nós vemos", permitiu aprofundar questões históricas e ecológicas da região para ampliação das perspectivas pedagógicas do projeto. A próxima seção deste texto é resultado desse trabalho, e o estudo incluiu não apenas um mergulho em fontes diversas da literatura histórica, como também se originou de palestras e textos preliminares por nós organizados. ${ }^{13}$

\section{O Brasil que Darwin viu}

Em 29 de fevereiro de 1832, quando o vapor Beagle fazia uma parada em Salvador, o jovem naturalista inglês Charles Darwin, em seu diário de viagem em torno do mundo, mostrou-se muito impressionado com o ambiente natural que começava a conhecer:

Deleite [sublinhou o autor] é uma palavra fraca para expressar os sentimentos de um naturalista que, pela primeira vez, esteve perambulando sozinho numa floresta brasileira. Em meio à profusão de objetos notáveis, a exube-

${ }^{11}$ Uma das escolas participantes desenvolveu um projeto com seus alunos e apresentou os resultados em dois congressos de ensino de biologia. Ver Cecchetti et al. (2001, 2002).

${ }^{12}$ Professoras Martha Abreu e Ana Angélica Barros, respectivamente.

${ }^{13}$ Selles, Pietszch e Ferreira (2001); Abreu e Selles (2002); Selles (2002). 
rância geral da vegetação ganha longe. A elegância das gramas, a novidade das plantas parasitas, a beleza das flores, $\mathrm{O}$ verde lustroso da folhagem, tudo leva a isso. ${ }^{14}$

Tendo chegado no início de abril daquele mesmo ano ao Rio de Janeiro, onde passaria aproximadamente três meses, Darwin registrou várias vezes esse tipo de deslumbramento.

Como nossa proposta pedagógica visava estimular a integração entre as disciplinas de biologia e história, e, ao mesmo tempo, propiciar o sentimento de pertencimento ao ambiente em que vivemos e atuamos, através de maior conhecimento e reflexão sobre a história da região e dos registros que recebeu, daremos destaque especial às observações do conhecido naturalista na viagem que fez por terra em direção ao norte de Cabo Frio. Nessa viagem Darwin passou por Niterói e Maricá. O relato ocupa praticamente a metade das páginas do capítulo intitulado "Rio de Janeiro".

A oportunidade da viagem de Darwin surgiu depois que um inglês, que acabara de conhecer, segundo as suas próprias palavras, o convidou para visitar sua propriedade, situada "a bem mais de 100 milhas da capital", às margens do rio Macaé. Darwin teria aceitado de "bom grado" a gentil oferta desse conterrâneo, pois, como registrou, "estava ficando desacostumado de viajar" 15 (ver no Mapa 1 o provável roteiro de Darwin).

Deixando, no dia 8 de abril de 1832, a cidade do Rio de Janeiro, então capital do Império do Brasil, o naturalista e seu grupo de sete pessoas rumaram na direção de Niterói. Quando "cruzavam as montanhas atrás da Praia Grande", nome da cidade de Niterói na época, Darwin escreveu: "A paisagem que se descortinava [...] era belíssima, pela intensidade das cores em que predominava o tom azul escuro; o céu e as águas calmas da baía rivalizavam entre si em esplendor."

\footnotetext{
${ }^{14}$ Darwin (1996, capítulo 1, p. 8).

${ }^{15}$ Como já informamos, todas as citações de Darwin sobre esta viagem podem ser encontradas no capítulo 2 de $O$ Beagle na América do Sul, p. 13-22. A descrição da estada no Rio de Janeiro encontra-se entre as páginas 22 e 23.
}

Depois de passarem por "alguns campos cultivados", Darwin avistou "uma floresta cuja magnificência", em sua opinião, "não podia ser superada [...]" Por volta do meio-dia chegaram a "Itacaia, um vilarejo" (mais próximo de uma sede de fazenda) numa "planície", onde, "em volta da casa central", estavam as "choupanas dos negros".

Se acompanharmos a descrição de Darwin em um mapa da região de meados do século XIX (ver Mapa 2), é possível a identificação dos campos cultivados, certamente açúcar e café, por trás das lagoas de Piratininga e Itaipu. O único trajeto possível para tal visão da magnífica floresta está assinalado no mapa por um círculo. Na legenda do mapa, significa estra$\mathrm{da}$, que margeia a exuberante cobertura vegetal da serra que já era conhecida como "Serra da Tiririca". A "Tiririca" é a última referência natural de tal envergadura antes de se chegar a "Itacaia" e, posteriormente, a Maricá e ao rio Macaé. Um razoável trecho da estrada que acompanha a Serra ainda hoje recebe o nome de Engenho do Mato, nome de um engenho que já se encontrava ali presente em meados do século XIX. ${ }^{16}$

Itaocaia é registrado no referido mapa como um morro, onde ao lado se podem identificar algumas plantações, provavelmente o "vilarejo" descrito por Darwin. O seu especial formato não deixou de ser percebido pelo naturalista viajante, que o descreveu como "um dos enormes morros de granito, íngremes e nus, tão comuns neste país". ${ }^{17}$

${ }^{16}$ Com a expansão do café no século XIX, é bastante provável que antigas fazendas de açúcar da região tenham também passado a plantar café. A própria área mais baixa da "Serra da Tiririca" foi bastante utilizada para esse cultivo. A recuperação da "Tiririca" teria acontecido posteriormente ao declínio do café e de outras culturas na região, aproximadamente no início do século XX. A divisão das terras das fazendas em lotes residenciais é um processo mais recente, que se acentuou com o crescimento da cidade de Niterói, após a década de 1980. Segundo consulta à bióloga Ana Angélica Barros, a Serra da Tiririca só guardou vegetação primária nas suas áreas mais altas.

${ }^{17}$ Este especial formato descrito por Darwin é que nos permite inferir que a Itaocaia do mapa significa a mesma Itacaia do naturalista (ver foto da capa e Foto 2). 
A partir de Itaocaia, as descrições dos marcos geográficos e naturais seguem o trajeto em direção à Lagoa de Maricá, marcado por "pântanos e lagunas". A estrada, segundo Darwin, "atravessava uma planície estreita e arenosa, entre o mar e as lagunas salgadas". No contorno da Lagoa de Maricá, Darwin teria feito um "almoço delicioso", em uma venda situada em um local onde se podia apreciar "bonita vista dos morros cobertos de vegetação, refletidos na águas absolutamente calmas de uma extensa laguna". Dali o grupo seguiu para o norte, uma região um pouco mais montanhosa ("100 pés de altura", nos cálculos do naturalista), em direção ao rio Macaé (ver Mapa 2).

Por esse rio, no dia 13 de abril, chegaram à fazenda Sossego, propriedade de Manuel Figuireda, parente de um dos membros da comitiva. Nessa região, onde ainda visitou outra fazenda, as descrições de Darwin indicam que se iniciava desbravamento das matas através da cultura do café. Além de o proprietário ter declarado que não tinha certeza das dimensões da fazenda, mostrando ser a área de ocupação recente, ainda podiam ser admirados, nas próprias palavras do naturalista, "belos objetos na floresta; entre eles, as samambaias que, embora não muito grandes, eram dignas de admiração por sua folhagem de um verde vivo".

Regressando da viagem, os registros de Darwin voltam-se para o Rio de Janeiro e para os passeios que fazia nas cercanias da cidade a partir de sua residência, um chalé na baía de Botafogo, bem embaixo do que denominou "célebre morro do Corcovado". Em suas próprias palavras, "nada pode ser mais surpreendente do que o efeito dessas imensas massas arredondadas de rocha nua emergindo de dentro da vegetação mais luxuriante".

\section{Darwin e a história}

Como vários outros naturalistas europeus que percorriam as Américas, no século XIX (por exemplo, Humboldt, Saint-Hilaire, von Martius, Pohl), em busca de novas e variadas espécies de plantas, animais e minerais, Charles Darwin, um ainda ilustre desconhecido de apenas 22 anos, maravilhava-se com as exuberantes singularidades do mundo tropical. Reconhecia que, apesar de a Inglaterra oferecer bons passeios para quem se interessava por história natural, "nesses climas férteis", como no Brasil, "as atrações são tão numerosas que mal se podia dar um passo".

Os objetivos de viagem de Darwin, entretanto, evidenciando uma tendência que já se esboçava com os naturalistas desde o século XVIII, tinham o sentido científico de organizar coleções e classificar tudo o que era observado. O desejo de viajar e colecionar não obedecia mais apenas a uma aventura em busca do exótico, mas à realização de um espírito científico, procurando examinar e comparar espécies, assim como estabelecer diferenças e semelhanças entre aquelas que existiam em regiões distantes. ${ }^{18}$

Em diversos momentos do relato de Darwin, encontramos descrições do reino animal, de vegetais e de minerais, e comparações diversas com espécies existentes na Europa. A coleta de plantas, flores, insetos, aves, peixes, fósseis e corais - uma moda de muito prestígio na Europa de então - foi tão significativa que parecia ser a melhor resposta às suas infinitas perguntas sobre o porquê de as coisas serem desta ou daquela maneira. ${ }^{19}$ Tudo o que via intrigava e desafiava a sua busca por explicações. O desafio que posteriormente ficou mais famoso, porque teria sido a base para a reflexão sobre a "origem das espécies", foi quando ele se encontrava nas Ilhas Galápagos e ficou intrigado com a existência de determinados pássaros em um arquipélago tão distante do continente.

Não podemos também deixar de pensar nestas viagens dos naturalistas como ligadas aos interesses das grandes potências européias do período, Inglaterra e França, em localizar pontos estratégicos de nave-

${ }^{18}$ Para uma análise das viagens de naturalistas ao Brasil no período colonial e século XIX, ver Kury e Sá (1999), Kury (2001) e Raminelli (2001).

${ }^{19}$ Segundo Michael Rose (2000), o material coletado por Darwin constituiu um dos tesouros mais consideráveis da história natural acumulados até aquela época. 
gação, comércio e identificação de riquezas. A viagem do Beagle, que por longos cinco anos, entre 1831 e 1836, circunavegaria o mundo, teria sido exemplar nesse sentido. Estava de acordo com os interesses do governo inglês, que visava localizar áreas estratégicas, principalmente minas e roteiros de navegação entre o Atlântico e o Pacífico, especialmente na América do Sul, para os seus investimentos e controle comercial. ${ }^{20}$

Apesar desses vínculos comerciais e políticos, as viagens não podem ser resumidas a isso. Ligados a universidades ou a associações científicas, esses intelectuais viajantes, além da busca pela comparação entre o Velho e o Novo Mundo, inseriam-se no movimento com um forte sentimento de missão civilizatória e filantrópica pelo progresso e bem-estar da humanidade. ${ }^{21}$ Em suas viagens, pretendiam avaliar as possibilidades de civilização e progresso dos diferentes povos e regiões, sendo que o parâmetro etnocêntrico europeu nunca deixou de ser fundamental. Na prática, eram os europeus os colecionadores, classificadores e identificadores das riquezas e potencialidades do Novo Mundo e de seus habitantes, o que reafirmava, em termos econômicos e intelectuais, a pretendida superioridade européia.

Na época de viagem de Darwin, já se encontrava enfraquecida ${ }^{22}$ a idéia de uma possível inferioridade ou degeneração da natureza das Américas, se compa-

${ }^{20}$ A partir dessas viagens, não era incomum o transporte de espécies vegetais para regiões onde elas inexistiam e poderiam ser exploradas, o que não deixava de ser um tipo de pirataria biológica.

${ }^{21}$ Essas sociedades, muito comuns desde o final do século XVIII, centralizavam as discussões e apoiavam o trabalho e as viagens científicas. Ver Prestes (2000).

${ }^{22}$ Mas não totalmente derrubada, pois ainda podem ser encontrados naturalistas e pensadores, como Nikolaus Lenau, que defendiam, na década de 1830, a inferioridade da natureza americana. Naturalistas norte-americanos, na frase de Gerbi (1996, p. 305), já haviam encontrado "fósseis de antiguidade indiscutível, pássaros de canto toleravelmente melodioso, indígenas suscetíveis de serem contagiados pela civilização”. rada à européia. As principais idéias de Buffon, De Pauw, Raynall e Robertson, que, dentre outros, defendiam essa inferioridade (em termos da geografia, zoologia, ${ }^{23}$ etnografia, climatologia, moral e filosofia da história), haviam sido bastante questionadas por muitos jesuítas na América hispânica, pelo padre mexicano Servando Teresa de Mier, por Thomas Jefferson, Thomas Paine e Benjamin Franklin (expressivos líderes da Independência dos Estados Unidos), e, principalmente, pelo cientista prussiano Alexander von Humboldt ${ }^{24}$, embora ainda fossem pairar muitas dúvidas sobre as oportunidades de civilização dos trópicos. Não tanto em razão do êxito dos brancos europeus aqui, mas fundamentalmente em razão da presença de índios, negros e mestiços. Quanto à inferioridade, ou não, a maior discussão do século XIX deixou de ser em torno da natureza, centrando-se nas oportunidades de civilização de povos mestiços e das sociedades que se erguiam nas Américas.

Nesta discussão sobre a comparação entre Europa e Américas, segundo Antonello Gerbi (1996), Darwin, em seu diário, teria destacado a grandeza da vegetação e dos animais das Américas, desafiando, então, as teorias de Buffon e mudando o enfoque da comparação que se costumava realizar. O naturalista, além de destacar a exuberância da floresta, o calor, as chuvas, a beleza, a diversidade da vegetação, não mais teria procurado o que era menor ou inferior em termos naturais, mas as singularidades..$^{25}$

Entretanto, a avaliação sobre o estágio de civilização dos povos não deixou de ser uma preocupação sempre presente nas descrições dos naturalistas via-

\footnotetext{
${ }^{23}$ Chegava-se a medir o tamanho dos animais e a comparar o canto dos pássaros.

${ }^{24}$ Humboldt influenciou muitos viajantes naturalistas europeus com a sua valorização da natureza americana.

${ }^{25}$ No capítulo sobre o Rio de Janeiro, Darwin faz comparações entre o Brasil e a Europa nos seguintes aspectos: a chuva, os besouros, as alfaces e os repolhos. É notória a influência do naturalista Humboldt nos registros de Darwin, que o cita mais de uma vez (apud Gerbi, 1996).
} 
jantes, pois a paisagem era entendida não apenas em termos naturais, mas incluía as populações e seus costumes. Registros do campo de discussão científica do final do século XVIII e início do XIX, os relatos dos viajantes tornam-se excelente fonte sobre a visão dos europeus a respeito da história e dos costumes dos povos das Américas. Natureza, homens e costumes, tudo, enfim, era classificado e ordenado, uma vez que se buscava uma comparação.

E Darwin, nesse aspecto, não fugiria à regra quando de sua viagem pelas cercanias de Niterói, pois descreveu a maior riqueza agrícola, o café, que então se expandia rapidamente pela província fluminense, tendo se tornado, nas décadas seguintes, a base econômica e política do Império brasileiro. Registrou as vendas e as moradias, fazendo avaliações sobre a sua boa adequação ao clima, embora algumas tenham sido avaliadas com tal "carência de conforto" que seria impossível achar na Inglaterra algo parecido. Relatou também os (maus) costumes dos proprietários dessas vendas e de algumas pessoas que conheceu. Por fim, não faltaram comentários sobre a alimentação, tida como abundante em razão da boa plantação de feijão e arroz, da quantidade de pasto e dos recursos da floresta, que ofereciam muitos animais de caça. Mas dentre os diversos costumes que atraíram o olhar do naturalista inglês, ao menos neste curto período em que viajou de Niterói ao norte de Cabo Frio, as cenas sobre a escravidão ocuparam lugar de destaque. Daremos especial atenção a isso.

\section{A história em Darwin}

Entre 1809, ano do nascimento de Charles Darwin, e o início da viagem do Beagle, em 1831, a Inglaterra passou por um agitado período político em virtude das reivindicações dos trabalhadores urbanos e do crescimento do movimento abolicionista. Em 1808, o Parlamento inglês votava a extinção do tráfico africano de escravos, apesar da oposição dos proprietários e comerciantes ligados ao infame comércio. Em 1823, uma grande revolta de escravos eclodia em Demerara (colônia inglesa no Caribe) e ajudava a ampliar as posições dos que defendiam a necessidade de se pôr fim à escravidão nos domínios ingleses, não só pela violência da repressão ao movimento revoltoso e pelo envolvimento de um pastor metodista inglês no caso, mas pelo crescimento da opinião que denunciava a desumanidade da escravidão e defendia o inexorável direito, tido como "natural" dos homens, à igualdade. ${ }^{26}$

A comunidade científica também se envolveu no debate, e poucos não foram atingidos pela idéia abolicionista. Charles Darwin, filho de uma rica e nobre família inglesa, educado para ser médico e posteriormente para ser clérigo, mais uma vez daria o testemunho de ser um homem de seu próprio tempo. Em seu diário, defendeu os negros e os escravos, denunciando repetidamente a barbárie da escravidão. As primeiras décadas do século XIX, herdeiras de todo o questionamento aos antigos privilégios de nascimento, inaugurados com a onda revolucionária francesa, foram marcadas - e não só na Inglaterra, mas em todo o mundo Atlântico, inclusive o Brasil - por ampla discussão a respeito dos direitos dos homens à liberdade e à igualdade. Darwin expressaria, em termos científicos naturalistas, um dos grandes desafios políticos da época: a igualdade dos homens em termos de sua própria origem. As idéias que circulavam sobre uma pretensa origem diversa da humanidade (teses poligenistas) justificavam as avaliações sobre a inferioridade dos africanos. Comecemos pelas suas próprias referências.

Nas cinco páginas em que descreve a sua viagem por terra de Niterói ao rio Macaé, Darwin refere-se, em três longas citações, ao problema da escravidão e dos escravos. Na primeira delas, cruzando a "Serra da Tiririca", logo depois de deixar o "pequeno

${ }^{26}$ O fim do tráfico e a abolição da escravidão nas colônias inglesas também estavam relacionados com o enfraquecimento político dos comerciantes ligados aos interesses das colônias do Caribe frente ao fortalecimento dos grupos industriais e defensores do livre cambismo no Parlamento inglês. Sobre o movimento abolicionista inglês, ver Costa (1998), capítulos 1 e 7. 
vilarejo de Itacaia", denuncia os preconceitos que sofrem os escravos. Em um daqueles enormes morros de granito - certamente o morro de Itaocaia -, Darwin registra que era famosa a história de uma "velha" que, ao ser capturada por soldados com seu grupo de quilombolas que se escondia no local, dali havia se atirado. Para Darwin, se o ato tivesse sido protagonizado por uma "matrona romana", seria "chamado de um nobre sentimento de liberdade. Numa pobre negra, era "apenas uma brutal obstinação". ${ }^{27}$

Na segunda passagem, já no rio Macaé, o naturalista preocupou-se com o tratamento dispensado aos escravos e avaliou que na fazenda visitada (Sossego), "se a idéia da escravidão pudesse ser deixada de lado [...]", seria possível dizer que os "escravos vivem satisfeitos e felizes", em virtude do estilo patriarcal de vida e dos direitos dos escravos ao produto do trabalho do final de semana.

Finalmente, na terceira longa passagem, "o último pedaço de terra cultivado que se vê" no rio Macaé, em sua avaliação, Darwin defendeu os "bons" sentimentos e os valores universais da humanidade, ao denunciar o proprietário e o que avaliou como "atos de atrocidade que só podem acontecer num país escravista": a venda, que acabou não se realizando, de mulheres escravas, sem seus filhos e maridos. Se o fato tivesse se consumado, Darwin lamentava que 30 famílias, "juntas por tantos anos", teriam sido separadas.

Ao continuar a registrar o que chamou de "história de crueldade", Darwin relata um caso, sem precisar o local e a época, deixando escapar uma expressão preconceituosa sobre um "negro" que o teria acompanhado em uma travessia de balsa. O tal "negro" do caso relatado pelo autor seria "incrivelmente estúpido", em sua avaliação, por não conseguir entendê-lo, depois de várias tentativas:

${ }^{27}$ Histórias sobre escravas que se jogaram da pedra de Itaocaia ainda vivem na região. Em artigo do jornal $O$ Fluminense, de 25/9/ 2000, o repórter Caio Barbosa registrou a existência de uma lenda na fazenda que fica próximo à pedra: segundo o informante (o atual caseiro da fazenda), uma escrava, ao ser encurralada por perseguidores, teria pulado lá de cima do penhasco de mais de 500 metros.
Tentando fazer-me entender, comecei a falar alto, a gesticular e, ao fazer isso, passei a mão perto de seu rosto. Ele, suponho, pensou que eu estava com raiva e ia bater nele, pois, imediatamente, com um olhar amedrontado e os olhos semicerrados, baixou os braços. Nunca esquecerei o meu sentimento de surpresa, desagrado e vergonha, ao ver um homem grande e forte com medo até mesmo de desviar-se de um golpe dirigido, como pensou ele, para seu rosto. Esse homem havia sido treinado para suportar uma degradação mais abjeta do que a escravidão do animal mais indefeso. (grifos nossos)

Expressões preconceituosas não eram incomuns entre os abolicionistas mais convictos, em razão das contradições que surgiam entre a defesa da abolição e a pretensa perversão dos valores e costumes que a escravidão teria imposto aos escravizados. No caso específico de Darwin, que até mesmo se declarou envergonhado, esta posição contraditória está presente, pois, pelas suas últimas palavras (que ressaltamos em itálico), a culpa deveria ser atribuída à própria escravidão, responsável pela "degradação" de seres "indefesos".

As críticas de Darwin à escravidão, entretanto, não encerram o pensamento do naturalista sobre a questão. Ao longo dessas três histórias, Darwin deu testemunho da luta de escravos fugidos, como os que "durante muito tempo" moraram no alto de um "daqueles enormes morros de granito" (a tal pedra de Itacaia/Itaocaia), conseguindo tirar sua subsistência do cultivo de um pequeno pedaço de terra perto do topo. Registrou a capacidade dos escravos de aprenderem uma profissão, ao descrever na fazenda Sossego o quadrilátero do café, que secava ao centro das principais construções: a casa do senhor, os celeiros, os estábulos e as "oficinas dos negros". Nas fazendas do rio Macaé, valorizou a existência da família escrava e a possibilidade de os escravos produzirem para si no trabalho agrícola aos sábados e domingos. Mesmo que tenha exagerado, registra que, no "clima fértil" do Brasil, "o trabalho de dois dias" seria "suficiente para garantir sustento de um homem e sua família por toda a semana".

Essas informações mencionadas por Darwin não 
são pequenos detalhes ou informações pouco confiáveis. Elas demonstram que o naturalista estava bastante inteirado dos debates sobre as possibilidades e os riscos da abolição no Caribe inglês, pois eles giravam em torno da capacidade, ou não, dos ex-escravos para o trabalho livre, para a organização e sustento de sua família, quando em liberdade. Pelos registros de Darwin em seu diário, o naturalista não parecia temer uma clara posição em favor dos escravos, de suas potencialidades e sentimentos. ${ }^{28}$

No entanto, suas impressões ajudam a confirmar os recentes resultados da pesquisa histórica sobre escravidão e abolição no Brasil e no Caribe em dois importantes sentidos: primeiramente, a importância do trabalho agrícola dos escravos aos domingos, quando podiam complementar a dieta alimentar de suas famílias e exercer atividades autônomas, sem o controle direto do senhor ou feitor; em segundo lugar, a existência de pequenos quilombos nas proximidades de fazendas ou de centros urbanos, como o que teria existido no morro de Itacaia/Itaocaia. ${ }^{29}$

Mas, para muito além da crítica à escravidão ou da defesa da capacidade dos escravos de viverem livres, Darwin ainda teria uma enorme importância na discussão sobre a idéia da igualdade entre os homens. No centro da questão, estaria a sua defesa sobre origem comum das espécies e da espécie humana em particular. A utilização dos registros históricos de Darwin exige uma reflexão sobre a dimensão intelectual e política que sua obra alcançou posteriormente, pois não se pode desconhecer que o seu autor se tornou um dos grandes marcos do pensamento intelectual do século XIX.

${ }^{28}$ De fato, Darwin iniciou sua viagem com tais convicções, pelo que se pode perceber quando registra, em sua autobiografia Minha vida, suas discussões e divergências com Fitz-Roy, capitão do Beagle: “[...] logo no início da viagem, na Bahia (Brasil), ele defendeu e louvou a abolição, que eu abominava" (apud FreireMaia, 1988, p. 29, grifos nossos). Sobre as várias etapas da vida de Darwin, ver também Desmond e Moore (2000).

${ }^{29}$ Ver Slenes (1999); Reis e Gomes (1996).

\section{Darwin na biologia e na história}

A publicação de Sobre a origem das espécies, em 1859, definitivamente garantiu o destaque de Darwin na comunidade científica, com a exposição de sua teoria sobre a evolução pela seleção natural. Idéia guardada por quase 20 anos, Sobre a origem logo se tornou um livro muito conhecido e muito vendido, pela objetividade do tratamento dado às teses defendidas e, obviamente, pelo seu impacto. Segundo Michael Rose (2000), até as teses de Darwin era impossível resolver o problema da semelhança entre as espécies de mamíferos ou insetos sem o recurso de idéias teológicas ou filosóficas. A imagem de uma enorme árvore, de onde as espécies descenderiam umas das outras, por um processo de mudança lenta e gradual, garantiria uma origem comum a todas as espécies, inclusive à espécie humana. ${ }^{30}$

$\mathrm{O}$ interesse pelo tema da origem da humanidade vinha crescendo desde o Iluminismo, que, no final do

${ }^{30}$ A aplicabilidade de sua teoria da descendência comum ao homem foi motivo de muita hesitação para Darwin. Em Sobre a origem, ele faz uma breve referência a essa questão: "para que nenhum homem honesto pudesse me acusar de ocultar minhas idéias, fiz referências através da obra em questão, que poderia lançar-se alguma luz sobre a origem do homem e sua história" (grifos nossos), principalmente porque se considerava "sem nenhuma evidência de minha convicção a respeito de sua origem". Parte de sua indecisão devia-se ao temor que o impacto dessas idéias teria, mas também porque suas idéias foram se aprimorando ao longo dos anos. Continua Darwin: "O meu Descendent of man foi publicado em fevereiro de 1871. Logo que me convenci, em 1837 ou 1838, de que as espécies eram produções mutáveis, não poderia evitar a convicção de que o Homem deve estar sob a mesma lei. [...] Mas quando vi que muitos naturalistas aceitavam plenamente a doutrina da evolução das espécies, me pareceu aconselhável dar forma às notas que possuía e publicar um tratado especial sobre a origem do homem". A inclusão do homem na teoria da evolução foi rejeitada até mesmo por Wallace, o que pode ser evidenciado por uma das cartas enviadas a ele por Darwin: “[...] embora não consiga convencê-lo, e isto para mim é o golpe mais forte que posso sofrer" (Darwin em Minha vida, apud Freire-Maia, 1988, p. 33). 
século XVIII, discutia em termos políticos e filosóficos os direitos dos homens à igualdade e à cidadania. Com a perda dos privilégios de nascimento que o Antigo Regime garantia, discussões acirradas seriam colocadas em torno da igualdade humana e do seu acesso aos direitos políticos. Quem teria direito à igualdade? Todos os homens eram iguais? O que definiria a igualdade? A mesma origem? O grau de "civilização" alcançado? A educação e o sucesso material, marcas dos que haviam conseguido sobreviver à "seleção natural"? Essas questões atravessaram o século XIX, quando também surgiu a idéia de raça, muito próxima à noção de povo e variante do debate sobre a cidadania (Schwarcz, 1993).

Para a questão que mais de perto nos interessa, a da "origem dos homens", existiam, resumidamente, até Darwin, duas teses: a monogenista e a poligenista. A monogenista, com origem em Rousseau, defendia a idéia de que a humanidade era una, embora diversa (e desigual) em seus caminhos; argumentava que todos os povos, mesmo diferentes, tinham possibilidades de aprimoramento e superação; a humanidade toda, se educada, estaria apta e fadada à civilização. A poligenista, pelo contrário, uma espécie de reação ao igualitarismo iluminista, sustentava a hipótese de que teriam existido vários centros de criação, correspondentes às diferenças da humanidade em termos raciais, de evolução e de comportamento (Schwarcz, 1993, p. 48).

Em um primeiro instante, ficamos tentados a pensar que as teses de Darwin ${ }^{31}$ colocariam por água abaixo as idéias defendidas pelos poligenistas. Ironicamente, na segunda metade do século XIX, em pleno período de expansionismo imperialista inglês - e europeu - por áreas onde se encontravam povos "diferentes", justificar-se-ia a dominação ocidental pela "natural seleção" daquele que se tornava o mais for-

${ }^{31}$ É interessante pensar que, apesar de ter criticado a idéia da "criação divina", Darwin, ao defender a origem una da humanidade, colocava-se do mesmo lado da Igreja católica, que entendia serem todos filhos do mesmo Deus. Ver Abreu (2001). te - os europeus ocidentais. Os poligenistas, mesmo tendo que se convencer da unicidade da espécie humana, minimizaram essa tese e passaram a argumentar que a separação das "espécies" já havia ocorrido há tanto tempo que era válido pensar em heranças e aptidões muito diversas. Na verdade, deram mais importância a outro princípio fundamental de Darwin: a seleção natural e o sucesso do mais forte na dura luta pela sobrevivência e reprodução. Prevaleceria o determinismo racial biológico, e até mesmo geográfico, sobre o direito de livre arbítrio dos seres humanos.

As relações entre o pensamento científico biológico e as teorias sobre os costumes, cultura e moral tornaram-se ainda mais estreitas, chegando a produzir julgamentos sobre as características e desenvolvimento dos povos e dos indivíduos em função de suas qualidades "naturais", como "hereditariedade", "raça", "cor", tamanho do cérebro (frenologia ou antropometria), região de origem etc. Assim, povos e pessoas passaram a ser avaliados como capazes, ou não, como condenados à barbárie ou à criminalidade, em razão da herança biológica que recebiam.

As teorias de Darwin acabaram dando base a um pensamento cientificista extremamente racista: o eugenismo. Tendo como grande representante o naturalista Francis Galton (aliás, parente de Darwin), o eugenismo faria longa carreira no pensamento ocidental, estigmatizando com a qualificação de degenerados os representantes de "raças impuras" e os herdeiros da miscigenação. A capacidade, o talento e o progresso estavam destinados aos que já eram tidos como mais fortes, os representantes da "raça branca", pretensamente pura e pretensamente vitoriosa na "competição" das espécies. ${ }^{32}$ A diferença entre os ho-

${ }^{32}$ Houve quem defendesse a direção da história da humanidade através do estímulo e desestímulo a determinadas uniões sexuais. Mas essa tarefa, até mesmo impossível de ser realizada, pelas dificuldades de controle da reprodução humana, acabou sendo inteiramente condenada. Não há raças humanas; não há, em termos científicos, diferenças biológicas e genéticas aceitáveis para que se justifique qualquer divisão da humanidade. 
mens passava a ser vista como definitiva e determinada pelos caracteres biológicos. ${ }^{33} \mathrm{~A}$ "raça" humana só poderia ser melhorada se fossem evitados cruzamentos indesejáveis. As crenças iluministas de que os homens eram naturalmente iguais, embora fossem marcados pela diversidade de caminhos e costumes, podendo se transformar pela ação da educação e civilização, ficavam seriamente abaladas.

A influência do pensamento de Darwin nas ciências humanas - antropologia, psicologia, linguística, pedagogia, sociologia, história, teoria política e economia - também foi intensa e profunda, fundando o que se costumou chamar de darwinismo social. Herbert Spencer, um de seus maiores defensores, foi quem primeiro expandiu a idéia de "sobrevivência do mais apto" às atividades econômicas e sociais. ${ }^{34}$ As discussões políticas sobre a "evolução e progresso", "competição e hereditariedade" da humanidade iam além da "origem das espécies" para reforçar o poder e a fortuna daqueles que já apareciam (e eram vistos) como os mais aptos e adaptados ao sucesso. ${ }^{35}$

${ }^{33}$ Esta visão do progresso para os mais fortes também esteve presente nas nações ditas civilizadas. Os pobres, por seu pretenso fracasso social, também foram vítimas desses estigmas e desqualificações.

${ }^{34}$ Além de Spencer, destacaram-se nessas diversas áreas $\mathrm{H}$. Magnus, Buckle, Franz Bopp, Gobineau, Gustave Le Bom, E. Renan, Taine etc. Em um interessante artigo publicado em Ciência Hoje, Ricardo Iglesias Rios (1999) destaca que a expressão "a sobrevivência dos mais aptos" inexistia nas duas primeiras edições de Sobre a origem das espécies. A frase teria sido criada pelo filósofo Herbert Spencer, e Darwin a teria incluído "nas últimas edições, por considerá-la mais acurada e algumas vezes mais convincente". Spencer foi um dos maiores divulgadores das teses de Darwin nas ciências sociais. Como afirma Rios, ironicamente, "Darwin não teve muita sorte com os seus admiradores" (p. 70).

35 Segundo Lilia Schwarcz (1993), o evolucionismo e o darwinismo social tiveram grande repercussão entre 1870 e 1930. A partir daí, passaram a receber duras críticas em todas as áreas de influência. Especialmente através da antropologia culturalista norte-americana, inaugurava-se uma nova etapa nas reflexões sobre as diferenças entre os povos e culturas, construindo-se o conceito de relativismo cultural.
Uma questão que precisa ser colocada é a seguinte: até que ponto Darwin era conivente com as apropriações sociais de suas teorias? Se uma única resposta é difícil, existem exemplos que mostram sua concordância com a expansão da civilização ocidental, via imperialismo inglês na Austrália, onde os animais e muitos grupos indígenas perdiam terreno para o "homem branco", "predestinado a herdar o território de seus filhos", nas próprias palavras do já célebre naturalista (apud Bizzo, 1987, p. 41). No mesmo sentido, em uma carta que escreveu em 1881, um ano antes de sua morte, pode-se encontrar a sua aceitação da categoria "raças inferiores":

[...] fazendo um relance sobre o mundo, sem olhar num porvir muito longínquo, quantas raças inferiores serão em breve eliminadas pelas raças (que chamamos caucásicas) que têm um grau de civilização superior. ${ }^{36}$ (apud Bizzo, 1987 , p. 68 , grifos nossos)

Entre o jovem Darwin naturalista do Beagle, de 1832, que viajou de Niterói ao rio Macaé sensível aos problemas dos humildes escravos, e o Darwin cientista famoso das décadas de 1870 e 1880, que "aceitava os conceitos de raças superiores e inferiores" (Rose, 2000, p. 167), muito tempo havia se passado. A Inglaterra tornara-se a maior potência mundial; os negros libertos não alcançaram a cidadania em nenhum país pós-escravista; e os operários ingleses passaram a ser vistos como "classes perigosas" (Schwarcz, 1993, p. 257). ${ }^{37}$

${ }^{36}$ Para Bizzo (1987), na publicação de 1871, Descendent of man, já podem ser encontrados vários registros sobre a defesa de Darwin da tese da seleção natural entre os homens pretensamente mais aptos. Entretanto, Lilia Schwarcz (1993, p. 257) argumenta que, em termos da miscigenação, os darwinistas sociais subverteram a tese de Darwin. O naturalista teria afirmado que os processos de hibridação não degeneravam; pelo contrário, como no caso do milho, a mistura produziria um produto mais resistente. A tese da degeneração da humanidade, caso a miscigenação prosperasse, era fundamental para os defensores do pensamento eugenista.

${ }^{37}$ Pelos limites deste artigo, não será possível um aprofundamento sobre as repercussões do darwinismo social no Brasil. O 
Se a idéia da igualdade entre todos os homens e, obviamente, todas as mulheres - ainda está longe de ser realidade, especialmente em nosso país, nada melhor do que refletir sobre as suas conquistas e reveses. Conhecendo um pouco dessa história - através do papel de Darwin e dos significados de suas idéias -, podemos ficar mais atentos às sempre novas justificativas - nem sempre tão novas assim - para as nossas persistentes desigualdades sociais e raciais. Podemos também pensar mais profundamente nas relações entre a biologia e a história.

\section{Caminhos entrecruzados entre a biologia e a história: contribuições pedagógicas}

A possibilidade de explorar um registro histórico tal qual a passagem de Darwin pela Serra da Tiririca mostrou-se um caminho frutífero para o trabalho com professores a respeito de um ambiente. Temos utilizado metaforicamente, por diversas vezes, a expressão "olhar sobre o ambiente" e, nesse sentido, podemos dizer que a lente principal da qual nos utilizamos foi oriunda da história. ${ }^{38}$ Obviamente, a opção por essa lente deveu-se a um conjunto de fatores. Entretanto, a notoriedade de Darwin como que nos levou a buscar, nas diversas possibilidades de encaminhar um trabalho voltado para professores, não apenas os marcos de sua passagem, mas diferentes sentidos de seus registros, diferentes formas de entender o pensamento dessa figura central para o pensamento biológico e, como vimos a partir de tantas apropriações, tam-

maior desafio para nossos intelectuais era encontrar um caminho de progresso e evolução para a nação, sendo ela profundamente mestiça. Tiveram que pensar na viabilidade de uma nação mestiça. Ver Schwarcz (1993), capítulos 3 a 6.

${ }^{38}$ No trabalho realizado com os professores, discutimos diversas possibilidades de utilizar também o olhar da geografia, cartografia, geologia, botânica, zoologia, ecologia, bem como encaminhar o trabalho na escola com a participação de professores de português, artes e outros, trazendo suas contribuições disciplinares. bém central para o pensamento humano. Lembra-nos Mayr (1998, p. 979), corroborado por Futuyma (1995), que, “À exceção possível de Freud, não há outro cientista sobre o qual se escreveu tanto e ainda se continua escrevendo, quanto Darwin".

É preciso ressaltar, entretanto, que a opção pelo uso da história pode ser empregada em suas diversas modalidades, como uso de registros históricos, história oral, memórias, história local, visões do homem sobre a natureza ao longo da história etc., uma vez que a notoriedade mais ampla de um personagem em um ambiente não pode ser o único critério de escolha. A passagem de Darwin pelos municípios de Niterói e Maricá foi, para nosso caso, uma oportuna coincidência. Tratando-se de um pensador do porte de Darwin, sua importância assumiu um caráter muito particular e por isso ensejou a reflexão sobre "Darwin na biologia e na história".

Como não tínhamos por alvo o ambiente em si mesmo, perguntávamos como a história construída a respeito desse ambiente nos permitiria vislumbrar relações que se deslocassem da biologia - com base nas leituras de Darwin - para outros campos disciplinares. Como vimos, a expressão do pensamento darwiniano vem atravessando as fronteiras da biologia, suscitando inúmeros questionamentos, associando dados de sua biografia, o cenário intelectual de seu tempo, bem como os impactos e as apropriações de suas idéias.

Nosso propósito não era apenas convidar o professor a revisitar os caminhos trilhados por Darwin, mas também ajudá-lo a perceber a trajetória de Darwin no seu tempo, as influências que teve, os olhares que lançou ao visitar nossa região. Um ambiente com as marcas dessa passagem, sem dúvida alguma, reforça, no professor e nos seus alunos, valores de pertencimento. Em virtude disso, uma leitura histórica de Darwin, como a que empreendemos, propiciou-nos uma reflexão mais aprofundada a respeito das influências teóricas sobre o pensamento darwiniano, como essas influências estavam presentes quando ele olhava o ambiente natural e como sua teoria reflete algumas dessas influências. Cabe ressaltar que essa for- 
ma de explorar o pensamento darwiniano não é usual na formação do professor de biologia.

O traço mais importante da visão de Darwin sobre o ambiente brasileiro, e que pode surpreender muitos biólogos, não é o do naturalista, sistematizador ou identificador de espécies novas. $\mathrm{O}$ aspecto que gostaríamos de destacar é reconhecer Darwin como um pensador de seu tempo e não um cientista alijado do seu contexto social, produzindo conhecimento biológico. Parece-nos importante refletir, de uma forma um tanto diferenciada da que é usual a um professor com uma formação básica em biologia, em que medida as idéias que Darwin carregava, as dúvidas e insatisfações que nutria em relação ao fixismo, sofreram o impacto da experiência brasileira, sobretudo no Rio de Janeiro, onde travou contato mais direto com a escravidão e com a variedade florística e faunística.

Nos cursos de graduação em biologia, ocupamonos mais em revelar um Darwin inquieto, meticuloso observador e colecionador em relação à diversidade do ambiente, do que em analisar as influências que teria recebido do mundo intelectual de onde procedia. ${ }^{39}$ Elkana (1970) chama a atenção para referências históricas de tipo heróico, que impregnam os livros escolares e produzem uma imagem mítica da ciência e dos cientistas. No exemplo particular de Darwin, esse princípio também se aplica, pois esse cientista é usualmente elevado à categoria de herói em detrimento até da co-autoria de Wallace! Nessa perspectiva, os graduandos em biologia reconhecem

${ }^{39}$ É preciso que se faça justiça a alguns livros textos empregados em cursos de biologia, como o clássico Biologia evolutiva, de Douglas Futuyma (1995), que dedica seu primeiro capítulo a discutir antecedentes históricos e biográficos relativos à elaboração da Teoria de Evolução; e ao professor Newton Freire-Maia, que inicia seu livro Teoria da evolução: de Darwin à teoria sintética (1988), com a autobiografia de Darwin. Em que medida os professores dos cursos de biologia acompanham a preocupação desses autores em apresentar os conteúdos biológicos conjugados a algum tipo de abordagem histórica, é uma questão que foge ao escopo deste trabalho. que as influências teóricas que teriam forjado a intelectualidade darwiniana se situam, quase que exclusivamente, nos domínios da ciência - a célebre influência de Lyell, a dos seus professores em Cambridge ${ }^{40} \mathrm{e}$ a leitura de Malthus. $\mathrm{O}$ tratamento dado às apropriações sociológicas do darwinismo aparece discretamente. Contamos uma história da construção desse conceito central e unificador da biologia baseada em dois pressupostos falsos, fazendo crer, primeiramente, que esse campo disciplinar já ocupava uma posição inequívoca na sociedade científica, e deixamos de acentuar que o impacto causado por essas idéias deu robustez ao processo de autonomia do conhecimento biológico. ${ }^{41}$ Mais do que isso, consideramos que as fontes sobre as quais Darwin se apoiou para desenvolver sua famosa teoria ${ }^{42}$ seriam, unicamente, as de caráter internalista, ou seja, oriundas da própria biologia. Mesmo Mayr (1998), em O desenvolvimento do pensamento biológico, amparado por uma literatura primária de tamanha densidade, é tímido nesse aspecto. Ressalta as bases da filosofia clássica na diferença entre o pensamento gradualista darwiniano e o essencialismo platônico-aristotélico que predominava no pensamento biológico do final do século XVIII, mas presta pouca atenção ao contexto socioistórico. O próprio Mayr reconhece isso quando afirma ter falhado em apresentar um contexto sociocultural do período darwiniano (1998, p. 961). Suas referências à influência de outros pensadores para além das fronteiras da biologia e estudos a respeito dessas outras fontes, buscando integrar o pensamento evolucionista às questões trazidas pelo Iluminismo, são pouco mencionados.

A questão que atormentava Darwin era a diversidade, conforme coloca Mayr (1998, p. 458): “os problemas da evolução e da diversidade continuaram a dominar o seu pensamento e os seus interesses”. Es-

${ }^{40}$ Os professores Henslow e Sedgwick, conforme afirma Darwin em Minha vida, de 1877 (apud Freire-Maia, 1988).

${ }^{41}$ Sobre esta questão, ver Prestes (2000).

42 Já nos referimos a isso anteriormente. 
tamos sugerindo que, ao olhar para o ambiente biológico, Darwin trouxe as marcas do pensamento de seu tempo como matriz - e as idéias iluministas a respeito da origem comum são parte delas - para as suas tentativas de explicar as questões cruciais a respeito da natureza humana e suas implicações sociais. Portanto, era importante para Darwin olhar, tanto para a exuberante diversidade biológica que o extasiava, quanto para as diferenças raciais, os diferentes tratamentos dados aos escravos, intrigando-se com os dilemas da igualdade em contraste com os da diversidade.

Dessa forma, as reflexões que trazemos com base em um estudo mais detalhado que recoloca Darwin na biologia e na história, e a história em Darwin, podem ampliar o horizonte do professor e incluir as diferentes possibilidades de articulação disciplinar, sobretudo no desenvolvimento de projetos relativos ao ambiente na escola. Auxiliam igualmente a reflexão sobre os conteúdos programáticos, as práticas pedagógicas utilizadas e sua conseqüente reelaboração, trazendo assim uma contribuição para o processo de contínua formação dos educadores. A exploração de um registro histórico levou-nos a desdobramentos teóricos que superam uma histórica factual sobre a vida e a obra de um cientista. Mais do que isso, articular os conhecimentos sobre um ambiente permite-nos desvendar surpreendentes fios na teia dos aspectos políticos, econômicos, culturais, sociais e éticos que o envolve. Esta nos parece ser uma possibilidade de transformação da sociedade e da visão de mundo impregnada pelo paradigma hegemônico de uma cientificidade que contraria os princípios defendidos pelos estudiosos do ambiente.

\section{Considerações finais}

A escola é um espaço em essência multidisciplinar e não pretendemos com estas considerações subverter uma lógica disciplinar, mas apenas sugerir que o entrecruzamento da biologia e da história configura uma parceria frutífera para abordar as questões focalizadas. Na atualidade, torna-se cada vez mais dese- jável, no processo de ensino-aprendizagem escolarizado, que esse caráter multidisciplinar possa ser interrelacionado, tomando como perspectiva um alargamento respeitoso das fronteiras disciplinares (Japiassu, 1991). As disciplinas e seus respectivos conteúdos, no entanto, na maioria das escolas, mantêm-se ainda compartimentalizados, não apenas por falta de contato entre os pares e pela dificuldade encontrada para que projetos multidisciplinares possam ser viabilizados, mas também porque estão assentados numa cultura escolar que foi constituída historicamente. É possível pensar em formas de enfrentamento dessas questões sem banalizar ou desrespeitar os constituintes dessa cultura. O trabalho em equipe, por exemplo, fornece uma alternativa viável e requer professores comprometidos com seu processo pessoal de expansão e exercendo sua capacidade de articulação com seus colegas de trabalho. Obviamente, obstáculos institucionais interpõem-se nessa iniciativa, mas essa tarefa se torna produtiva e gratificante quando colocada em prática. Na verdade, as condições institucionais exercem um papel importantíssimo na criação de espaços de discussão e de trocas entre os professores, e é preciso que o professor redimensione seus limites no espaço institucionalizado da escola, sem abrir mão de seus ideais (Behrsin e Selles, 2001).

Consideramos que o uso de um registro histórico como tema gerador de projetos de educação ambiental se mostra enriquecedor para o desenvolvimento de uma consciência ambiental, não apenas porque consegue articular conteúdos curriculares, mas, sobretudo, porque resgata valores de ordem cultural e amplia a visão do ambiente. A tentativa de ressignificar o conhecimento cotidiano do ambiente natural ameaçado permite identificar relações temporais que elevam a vivência de um "tempo profundo" do qual todos compartilham (Sacks, 1997), ou, como prefere Brandão (1999), desenvolvem um "afeto" pela terra.

MARTHA ABREU, doutora pela UNICAMP, em 1996, é professora do Departamento de História da Universidade Federal Fluminense e pesquisadora do CNPq. Publicou: $O$ império do divino, festas e cultura popular no Rio de Janeiro do século XIX 
(Rio de Janeiro: Nova Fronteira, 1999). Redigiu também diversos verbetes do Dicionário do Brasil Imperial (Rio de Janeiro: Objetiva, 2002). Atualmente, pesquisa a relação entre o estudo das manifestações culturais (festas, músicas e danças) populares e negras e a formação de uma pretensa identidade nacional brasileira entre 1870 e 1920. E-mail: marthabreu@nitnet.com.br.

SANDRA ESCOVEDO SELLES, doutora pela University of East Anglia, em 1992, é professora da Faculdade de Educação, da Universidade Federal Fluminense. Publicou: Formação continuada de professores de ciências e desenvolvimento profissional, (Ensaio - Pesquisa em Educação em Ciências, Belo Horizonte, dezembro de 2000, p. 209-229); com Ayres, A. C. e Reznik, T., Models of the human circulatory system in science textbooks: building a framework for representation analysis (In: García-Rodeja, Isabel Gayoso; Díaz, J. de B.; Harms, U.; Jiménez, M. P. A. (eds.) III Conference of European Researchers in Didactic of Biology - Proceedings, Santiago de Compostela, Universidade de Santiago de Compostela, 2001, p. 217-228). Pesquisa atualmente questões relacionadas com a formação inicial e continuada de professores de ciências/biologia e com o ensino e aprendizagem em ciências/biologia, enfatizando o papel de modelos mentais e modelagem/modelização. E-mail: seselles@ar.microlink.com.br.

\section{Referências bibliográficas}

ABREU, Martha, (2001). Pensamento católico, abolicionismo e festas religiosas no Rio de Janeiro, 1870-1890. In: PAMPLONA, M. A., (org.). Escravidão, exclusão e cidadania. Rio de Janeiro: Access.

ABREU, Martha, SELLES, Sandra E., (2002). O Brasil que Darwin viu. Palestra proferida no VIII Encontro Perspectiva do Ensino de Biologia. São Paulo: Faculdade de Educação da USP, Mimeo.

BARZANO, Marco Antonio L., (2000). Concepções de meio ambiente na formação de professores de ciências e biologia. Dissertação de Mestrado. Niterói, Universidade Federal Fluminense.

BEHRSIN, Maria Cristina D., (2001). Formação continuada docente: reflexões a partir das vozes de professores participantes de curso de pós-graduação lato sensu em ensino de ciências. Dissertação de Mestrado. Niterói, Universidade Federal Fluminense.
BERHSIN, Maria Cristina D.; SELLES, Sandra E., (2001). Formação continuada docente: reflexões a partir das vozes de professores participantes de curso de pós-graduação lato sensu em ensino de ciências. In: SELLES, Sandra E., FERREIRA, Márcia S., MARANDINO, Martha, AYRES, Ana Cléa (orgs.). Anais do I EREBIO. Niterói: SBEnBio, p. 96-100.

BIZZO, Nélio M., (1987). O que é darwinismo. São Paulo: Brasiliense.

BRANDÃO, Carlos R., (1999). O afeto da terra. Campinas: Editora da UNICAMP

BRÜGGER, Paula, (1994). Educação ou adestramento ambiental? Florianópolis: Letras Contemporâneas.

CECCHETTI, Fabio, ARAÚJO, André F., MARTINS, Luíza D., CARVALHO, Maira C. de A., (2001). Abordagem de conceitos darwinistas em jogo multidisciplinar. In: Anais do I EREBIO. Niterói: SBEnBIO, p. 419-420.

(2002). Abordagem de conceitos darwinistas em jogo multidisciplinar. In: Coletâneas do VIII Encontro de Perspectivas de Ensino de Biologia. São Paulo: Faculdade de Educação da USP.

COSTA, Emília Viotti, (1998). Coroas de glória, lágrimas de sangue; a rebelião dos escravos de Demerara, em 1823. São Paulo: Cia das Letras.

DARWIN, Charles, (1937). Diário de um naturalista ao redor do mundo. Brasil Ed. Tradução de J. Carvalho.

, (1996). O Beagle na América do Sul. Rio de Janeiro: Paz e Terra. Tradução de Lia Vasconcelos.

DESMOND, Adrian, MOORE, James, (2000). Darwin, a vida de um evolucionista atormentado. $3^{\text {a }}$ ed. São Paulo: Geração Editorial.

DIAS, G. F., (1998). Educação ambiental: princípios e práticas. $5^{\text {a }}$ ed. São Paulo: Global.

ELKANA, Y., (1970). Science, philosophy of science and science teaching. Education, Philosophy \& Theory, v. 2, p. 15-35.

FREIRE-MAIA, Newton, (1988). Teoria da evolução; de Darwin à teoria sintética. São Paulo: Editora da USP.

FUTUYMA, Douglas, (1995). Biologia evolutiva. Ribeirão Preto: Sociedade Brasileira de Genética/CNPq.

GERBI, Antonello, (1996). O novo mundo, a história de uma polêmica, 1750-1900. São Paulo: Cia das Letras. 
GRÜN, Mauro, (1996). Ética e educação ambiental: a conexão necessária. Campinas: Papirus.

JAPIASSU, Hilton, (1991). Introdução ao pensamento epistemológico. Rio de Janeiro: Francisco Alves.

KURY, Lorelay, (2001). Viajantes e naturalistas do século XIX. In: PEREIRA, P. R. (org.). Brasiliana da Biblioteca Nacional. Rio de Janeiro: Nova Fronteira / MEC / Fundação Biblioteca Nacional.

, SÁ, Magali R., (1999). Os três reinos da natureza. In: $O$ Brasil redescoberto. Rio de Janeiro: Paço Imperial / MinC-IPHAN.

LAYARGUES, Phillipe P., (2001). A resolução de problemas ambientais locais deve ser um tema-gerador ou a atividadefim da educação ambiental? In: REIGOTA, M. (org.). Verde cotidiano; o ambiente em discussão. Rio de Janeiro: DPA

MAYR, E., (1998). O desenvolvimento do pensamento biológico. Brasília: Editora da UnB.

PRESTES, Maria Elice B., (2000). A investigação da natureza no Brasil colônia. São Paulo: Annablume / FAPESP.

RAMINELLI, Ronald, (2001). Viagens e história natural dos séculos XVII e XVIII. In: PEREIRA, P. R. (org). Brasiliana da Biblioteca Nacional. Rio de Janeiro: Nova Fronteira / MEC / Fundação Biblioteca Nacional.

REIGOTA, Marcos, (org.), (2001). Verde cotidiano; o ambiente em discussão. Rio de Janeiro: DPA.

REIS, J. J., GOMES, F. S., (1996). Liberdade por um fio; história dos quilombos no Brasil. São Paulo: Cia das Letras.

RIOS, Ricardo I., (1999). Um livro ainda muito atual. Ciência Hoje, v. 26, n. 152

ROSE, Michael, (2000). O espectro de Darwin. Rio de Janeiro: Jorge Zahar Editor.

SACKS, Oliver, (1997). A ilha dos daltônicos. São Paulo: Companhia das Letras.

SCHWARCZ, Lilia M., (1993). O espetáculo das raças. São Paulo: Cia das Letras.

SELLES, Sandra E., (2002). Darwin na Serra da Tiririca: o uso de registros históricos em trabalhos ambientais. Palestra pro- ferida no Instituto de Física da Universidade Federal Fluminense, Mimeo.

SELLES, Sandra E., PIETSZCH, Lori L., FERREIRA, M. J. M., (2001). Uso de registros históricos como tema gerador em projetos de educação ambiental. In: Anais do I EREBIO. Niterói: SBEnBIO.

SLENES, Robert, (1999). Na senzala, uma flor, esperanças e recordações na formação da família escrava; Brasil, sudeste, século XIX. Rio de Janeiro: Nova Fronteira.

VIANNA, Aline V., (2002). A educação ambiental nos contextos escolares: para além da limitação compreensiva da incompreensão discursiva. Dissertação de Mestrado. Niterói, Universidade Federal Fluminense.

\section{Cronologia}

1808 - Fim do tráfico inglês de escravos

1809 - Nascimento de Darwin

1823 - Revolta em Demerara e propostas no Parlamento para abolição e/ou melhoria de tratamento dos escravos nas colônias inglesas

1831 - Partida do Beagle para a volta ao mundo

1833 - Abolição da escravidão nas colônias inglesas, com um prazo para a "aprendizagem" dos escravos e futuros libertos

1836 - Volta de Darwin à Inglaterra

1838 - Abolição final da escravidão nas colônias inglesas, com indenização aos proprietários. Vitória dos ideais ingleses de liberdade, ordem e prosperidade. Nova legitimidade da Monarquia com a rainha Vitória: extensão do sufrágio e do imperialismo.

1859 - Publicação de Sobre a origem das espécies

1871 - Publicação de Descendência do homem

1882 - Morte de Darwin

1888 - Abolição da escravidão no Brasil 


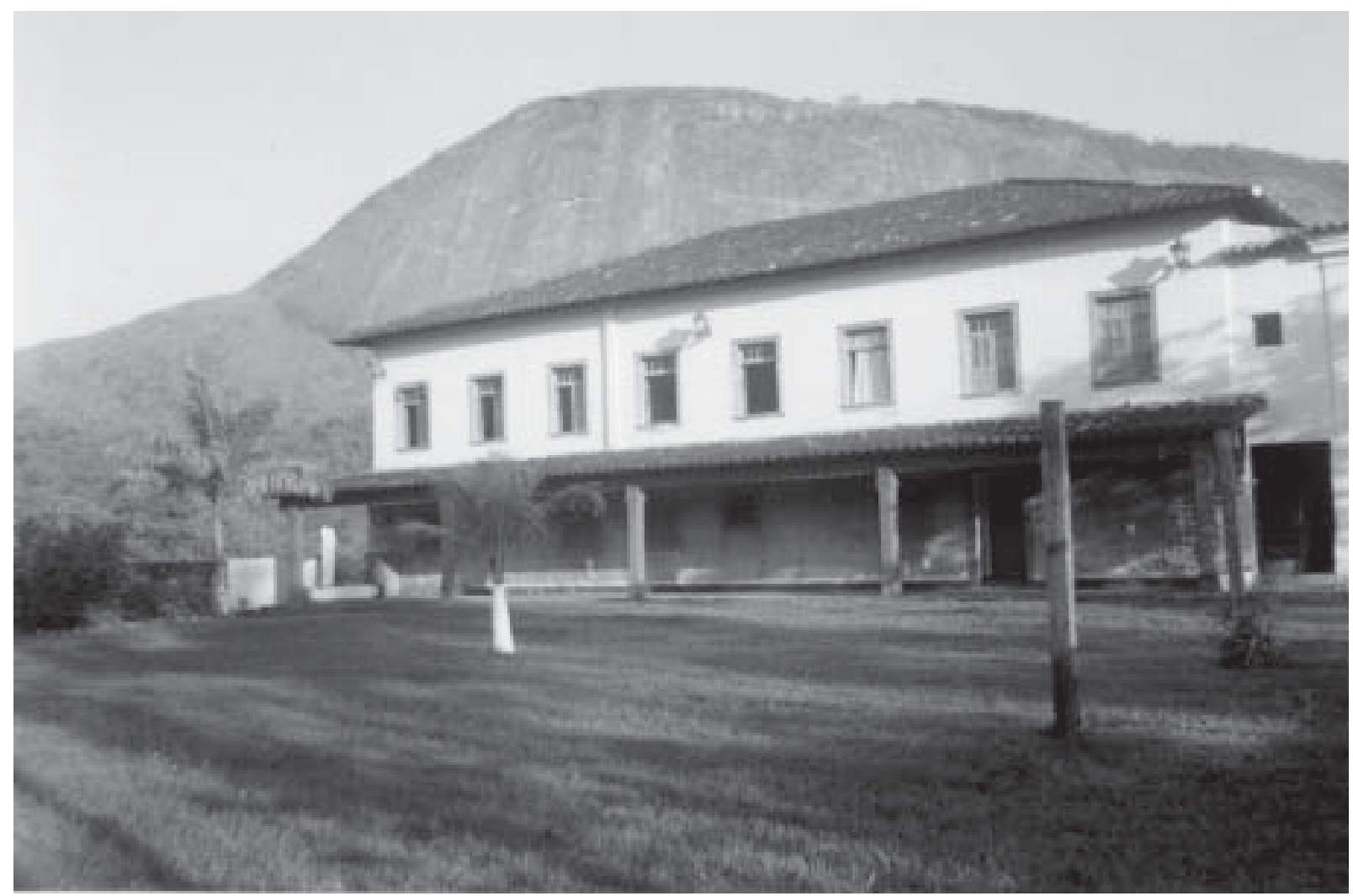

Foto 1 - Casa central do Engenho Sossego, hoje sede do Hotel Fazenda Século XVIII

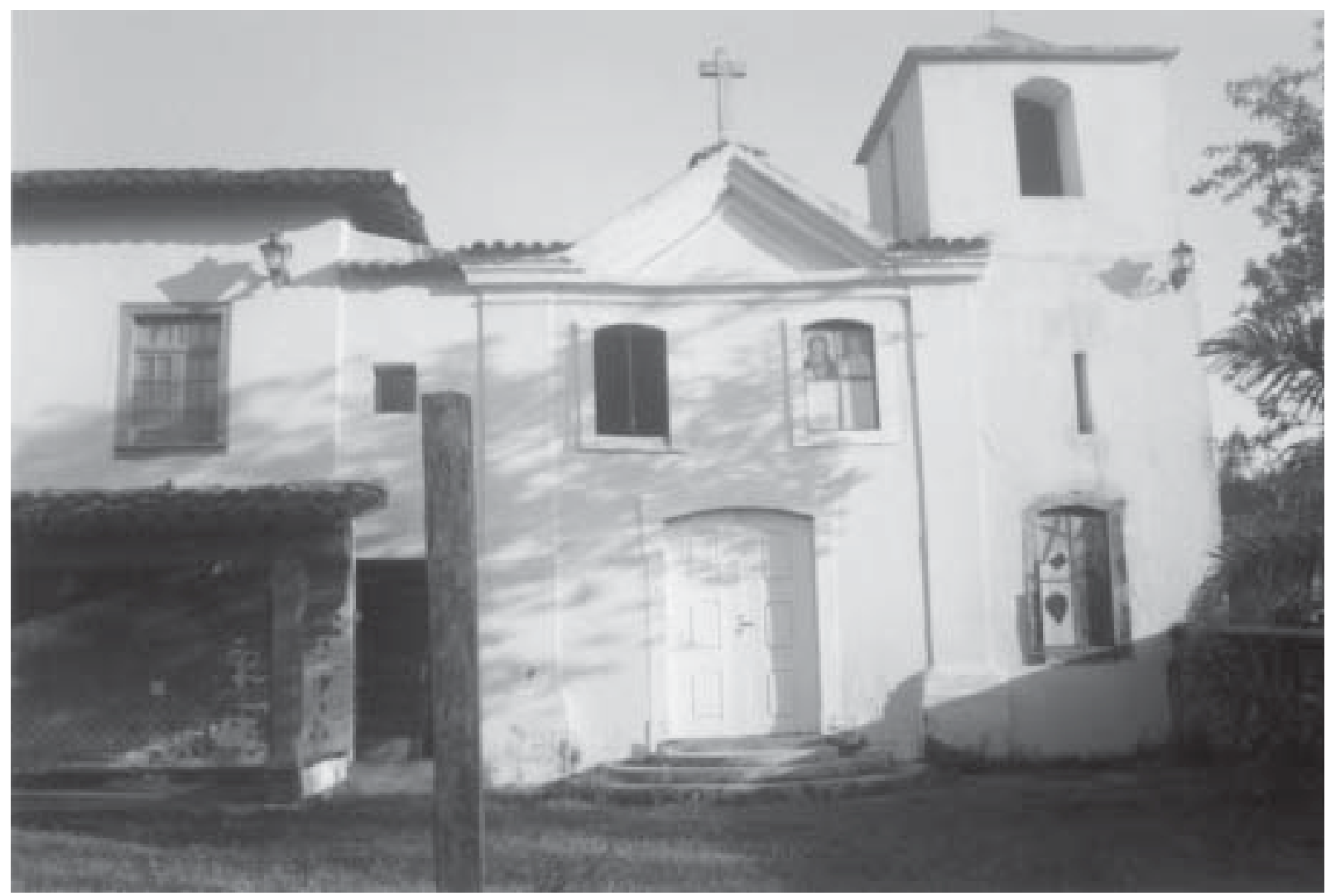

Foto 2 - Capela, complemento da casa central do Engenho Sossego 


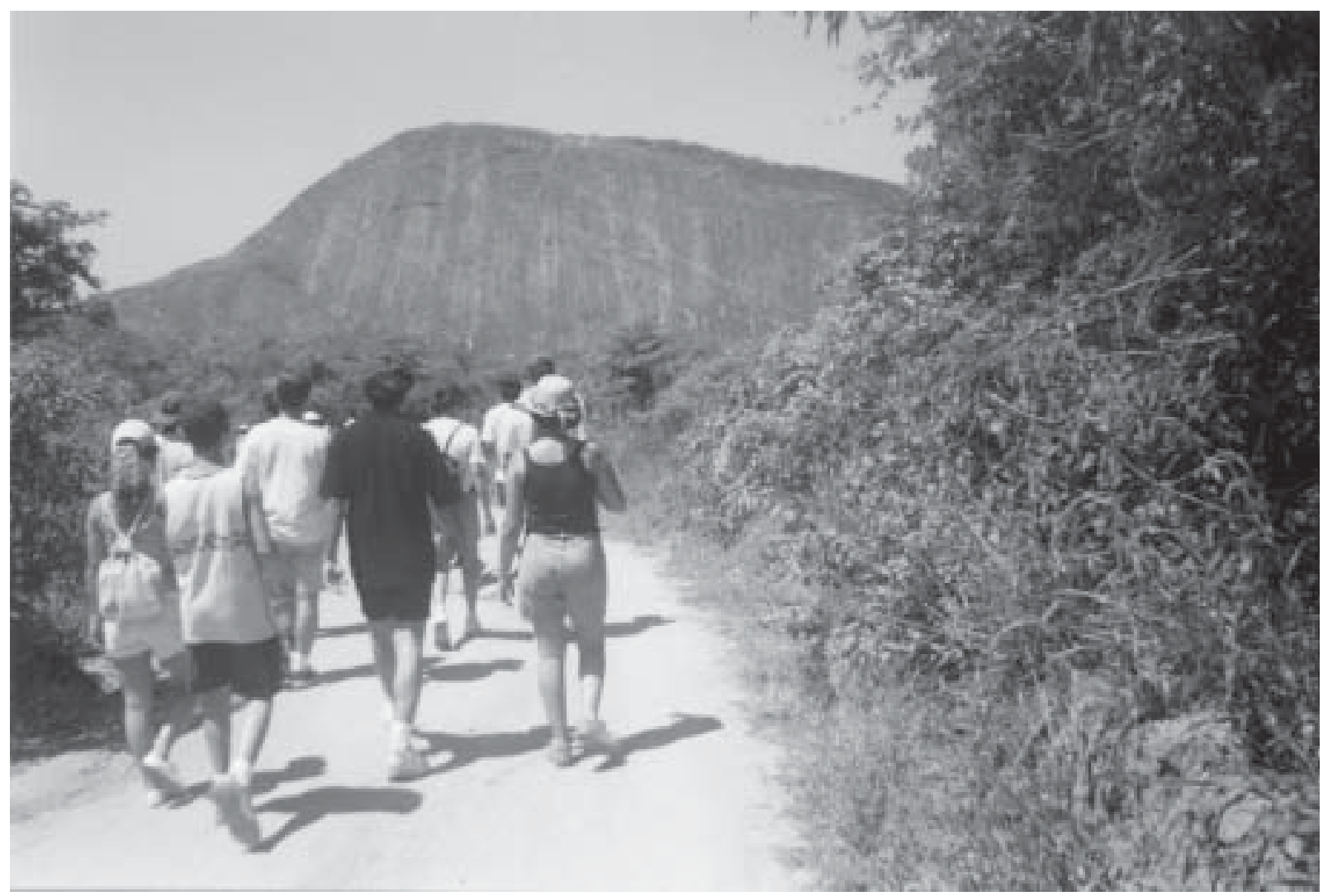

Foto 3 - Início da caminhada, com a pedra de Itaocaia ao fundo

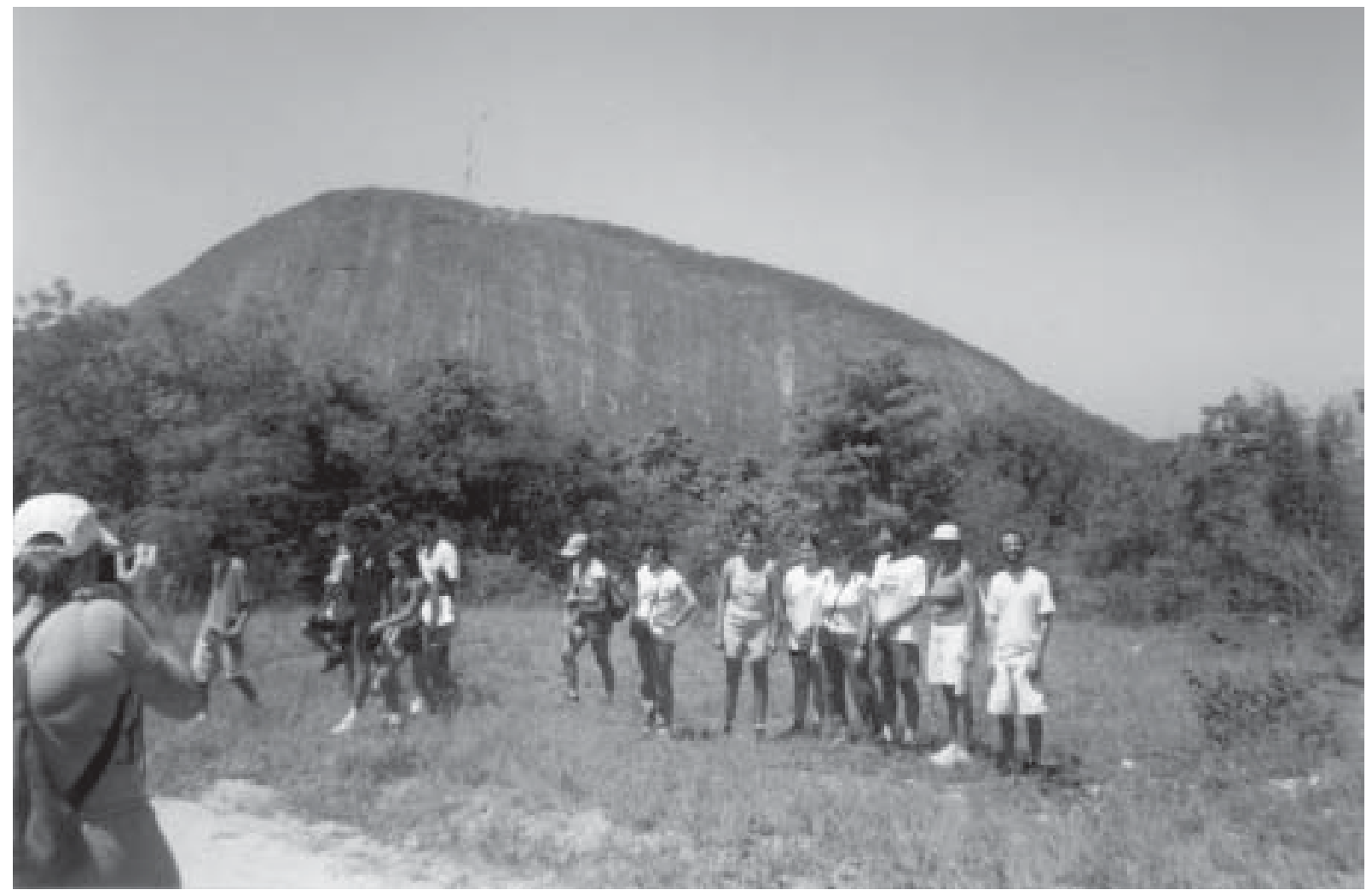

Foto 4 - Registro da atividade realizada 


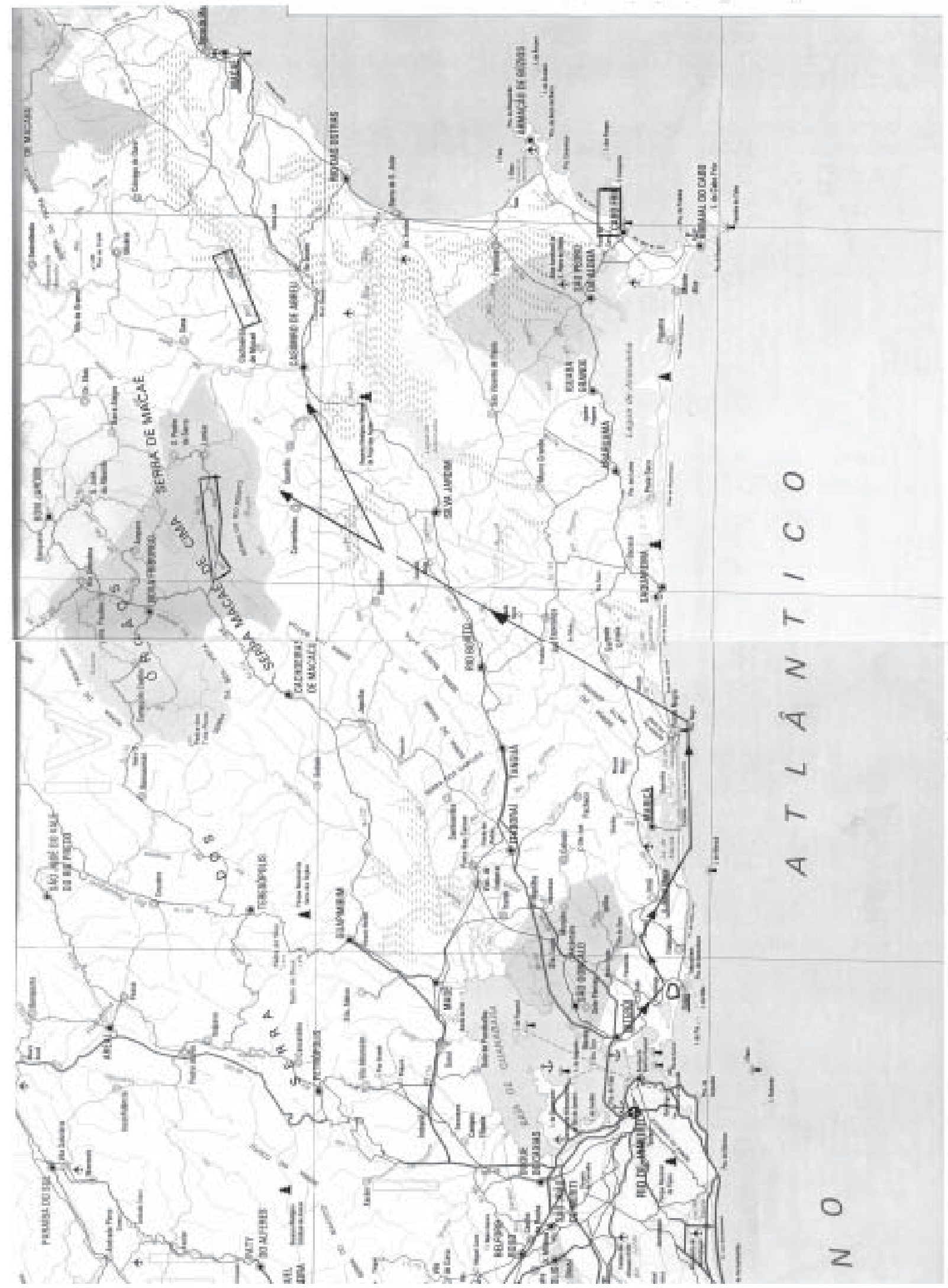

Mapa 1 - Provável percurso de Darwin em direção ao rio Macaé, ao norte de Cabo Frio 


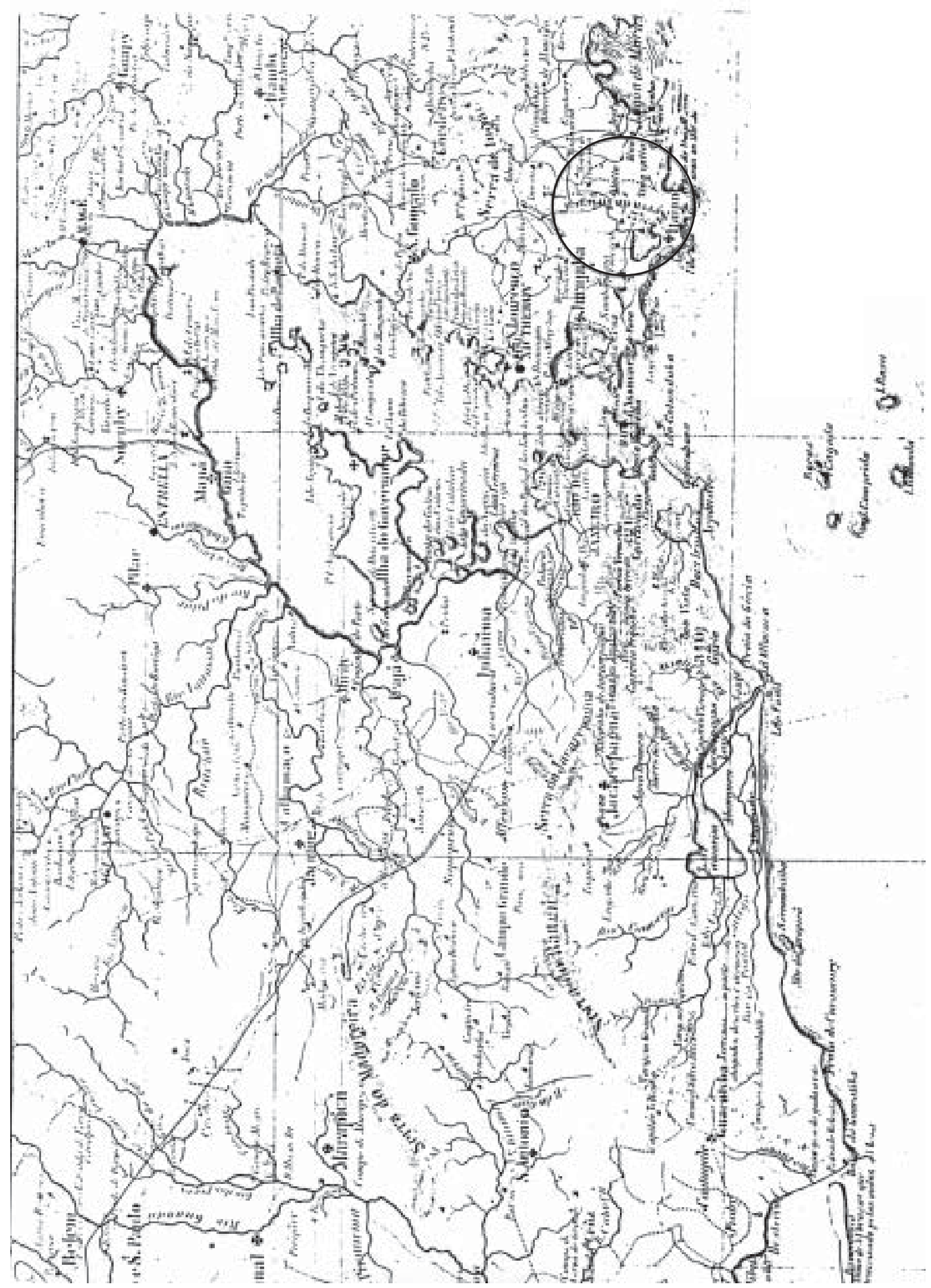

Mapa 2 - Carta elaborada por Nicoláo Tolentino em 1851. Escala 1:300.000. A circunferência do círculo marca a área da Serra da Tiririca. 


\section{Resumos/Abstracts}

Sandra Escovedo Selles e

Martha Abreu

\section{Darwin na Serra da Tiririca}

Este artigo apresenta uma experiência de pesquisa, ensino e extensão, realizada por duas professoras da área de biologia e história da Universidade Federal Fluminense, sistematizando os principais passos, conteúdos e resultados da iniciativa. A experiência teve como motivação inicial os relatos de Charles Darwin, quando visitou o Brasil em 1832, particularmente quando, de Niterói, se dirigiu ao norte de Cabo Frio e registrou suas observações em um diário, posteriormente publicado. Como nesses registros se encontravam citados aspectos do ambiente natural e social próximo ao atual Parque Estadual da Serra da Tiririca (região fronteiriça entre os municípios de Niterói e Macaé), procuramos refletir sobre as possibilidades de se estudar o ambiente com vistas ao desenvolvimento de valores, principalmente aqueles ligados à formação de sentimentos de pertencimento e à valorização de um local. Para além da própria importância da presença de Darwin na região, destacamos a necessidade de contextualizar as idéias do autor nos conflitos teóricos e políticos de seu próprio tempo, assim como compreender as palavras de Darwin sobre a natureza e sobre as relações sociais escravistas daquele local e período, como reflexão e estímulo para a criação de sentimentos de pertencimento ao local.

Palavras-chave: ecologia, história e biologia.

\section{Darwin in the Tiririca Mountain Range}

Presents an experience in research, teaching and extension undertaken by two university lecturers from the fields of Biology and History, at the Federal Fluminense University, and systematises the principal steps, contents and results of the initiative. The initial inspiration for the experience were Charles Darwin's reports on his visit to Brazil in 1832 and, in particular, on his journey north from Niteroi to Cabo Frio during which he registered his observations in a diary which was later published. Since these reports contain references to the natural and social environment close to the present State Park of the Tiririca Mountain Range (a region on the border between the municipalities of Niteroi and Macaé), we seek to reflect on the possibilities of studying the environment with a view to developing values, chiefly those linked to creating feelings of belonging to and valorising a place. In addition to the importance of the presence of Darwin in the region, we emphasise the need to contextualise the author's ideas in the theoretical and political conflicts of his own time as well as understanding
Darwin's words about the nature and social relations of slavery of that place and period, as a reflection and stimulus for the creation of feelings of belonging to the locality. Key-words: ecology, history, biology.

Antônio Augusto Gomes Batista, Ana Maria de Oliveira Galvão e Karina Klinke

\section{Livros escolares de leitura: uma} morfologia (1866-1956)

$\mathrm{O}$ artigo busca, a partir dos resultados parciais de uma pesquisa mais ampla, descrever a morfologia do livro escolar de leitura, no período de 1866 a 1956.

Os livros escolares constituem a principal fonte da pesquisa, particularmente aqueles que compõem o acervo do CEALE/UFMG, tomados, na investigação, como um caso provável de biblioteca escolar e, desse modo, como indicadores indiretos da produção editorial brasileira do período. Da análise realizada, apreenderam-se dois grandes tipos de livros (séries graduadas e livros isolados), quatro grandes gêneros (compêndios, antologias, narrativas e caderno de atividades) e cinco grandes modelos de livro (paleógrafo, instrutivo, formativo, retórico-literário e autônomo). A análise permitiu, ainda, identificar quatro ordens de fenômenos cuja participação na conformação dessas características é preciso melhor conhecer: a progressiva distinção entre 